\title{
Illicit Exploitation of Natural Resources
}

\author{
DANIËLLA DAM DE JONG AND JAMES G. STEWART
}

\section{INTRODUCTION}

Article 28A(1)(13) of the Protocol to the Statute of the African Court of Justice and Human Rights ('The Protocol') lists 'Illicit exploitation of natural resources' as a criminal offence within the Court's jurisdiction (hereafter 'Illicit Exploitation'). The Protocol goes on to define Illicit Exploitation as including seven different sub-offences - sometimes vague, often groundbreaking - that might attract criminal responsibility under the aegis of this new crime. ${ }^{1}$ The sole limiting criterion is whether acts of illicit exploitation of natural resources are 'of a serious nature affecting the stability of a state, region or the Union'. In conjunction with the new mandate of the African Court, which includes the exercise of jurisdiction over corporations for the first time

I wish to thank my colleagues Dr. Mamadou Hébié and Dr. Sergey Vasiliev for their valuable comments during the drafting of this chapter. Any remaining mistakes of course are my own.

1 Art. 28L Bis of the Protocol, entitled "Illicit Exploitation of Natural Resources", reads:

For the purpose of this Statute, 'Illicit exploitation of natural resources' means any of the following acts if they are of a serious nature affecting the stability of a state, region or the Union:

(a) Concluding an agreement to exploit resources, in violation of the principle of peoples' sovereignty over their natural resources;

(b) Concluding with state authorities an agreement to exploit natural resources, in violation of the legal and regulatory procedures of the State concerned;

(c) Concluding an agreement to exploit natural resources through corrupt practices;

(d) Concluding an agreement to exploit natural resources that is clearly one-sided;

(e) Exploiting natural resources without any agreement with the State concerned;

(f) Exploiting natural resources without complying with norms relating to the protection of the environment and the security of the people and the staff; and

(g) Violating the norms and standards established by the relevant natural resource certification mechanism. 
in an international treaty, the prohibition of 'illicit exploitation of natural resources' creates an offence with especially sharp teeth, for businesspeople, their corporations, military actors and politicians. The crime constitutes an important innovation in international law, since it offers a distinct legal basis for prosecution of a wider array of acts covered by the war crime of pillage. ${ }^{2}$ Nonetheless, it also comes with a set of major limitations, not the least of which is its great vagueness.

This chapter offers a critical doctrinal overview of the seven sub-offences that fall within the wider banner of this new crime of Illicit Exploitation, simultaneously pointing to a range of interpretative possibilities that might accord with recent thinking about the relationship between law and resource predation. We include a set of recurring shortcomings with the provision as drafted in The Protocol even though we agree that accountability for resource predation in Africa is long overdue. Our overall impression is that the provision is overly broad and insufficiently precise in many manifestations of its form, but we hope that what follows functions as an introduction of sorts, which other scholars will use as a point of departure for far more detailed scholarly treatment. Accordingly, we divide this chapter into three parts. In section one, we situate the novel crime within pre-existing avenues for regulating illegal exploitation of natural resources in international law. In section two, we go on to examine the scope of the provision, focusing on its chapeau and the seven different sub-offences it covers. The chapter concludes in section three with a brief overview of the crime's strengths and weaknesses.

\section{SitUATING THE NOVEL CRIME}

Symbolically, the criminalization of illicit exploitation of natural resources is both significant and timely. With the formulation of a novel international crime of illicit exploitation of natural resources, the African community has taken an important step in addressing one of its major concerns in recent decades. The illicit exploitation of natural resources is associated with the financing of armed conflicts, which unsurprisingly, has very negative effects on local populations' enjoyment of basic human rights, physical security and economic wellbeing. Over the past decades, natural resources have become

2 Pillage was also the legal basis for the International Court of Justice to hold the Ugandan State responsible for the looting by Ugandan soldiers of the natural resources of the DR Congo. See International Court of Justice, Armed Activities on the Territory of the Congo (Democratic Republic of the Congo v. Uganda), Judgment of 19 December 2005, I.C.J. Reports 2005, para. 245 . 
one of the principal sources of revenue for armed groups, replacing Cold War superpower sponsorship. ${ }^{3}$ In armed conflicts in Angola, Sierra Leone, Côte d'Ivoire, the DR Congo and the Central African Republic, natural resources did not necessarily provide the sole means or motivations for armed violence, but they were at least one of several important causal factors that helped sustain bloodshed. Thus, this new offence of illicit exploitation of natural resources represents an important symbolic response to much publicized issues in a variety of African war zones.

The problems that flow from the illegal exploitation of natural resources are by no means limited to the funding of armed conflicts, however. An investigation led by various international organizations in the Democratic Republic of Congo (DRC), for instance, concluded that around 98 per cent of net profits from illegal natural resource exploitation in the DRC - particularly gold, charcoal and timber - goes to transnational organized criminal networks, while armed groups retain only 2 per cent of these profits. ${ }^{4}$ This blurring is typical of present day warfare, which is characterized by an important interaction between the local and the global, and which resembles private enterprise more than traditional ideologically motivated battles between military groups. ${ }^{5}$ Aside from organized crime, illicit exploitation is also a key component in kleptocratic governance, a frequent part of endemic corruption and illegal tax evasion, ${ }^{6}$ and a central driver of the famed resource curse, whereby the richest countries in terms of natural resource endowment are, very counterintuitively, the poorest in terms of standards of living. ${ }^{7}$ Thus,

3 See K. Ballentine \& J. Sherman (ed.), The Political Economy of Armed Conflict: Beyond Greed and Grievance, International Peace Academy (Boulder/London: Lynne Rienner Publishers 2003), at $1-3$.

4 UNEP-MONUSCO-OSESG, 'Experts' background report on illegal exploitation and trade in natural resources benefitting organized criminal groups and recommendations on MONUSCO's role in fostering stability and peace in eastern DR Congo', Final report, 15 April 2015, available at www.unep.org (last visited i February 2016).

5 See on this e.g. M. Kaldor, New and Old Wars: Organized Violence in a Global Era (Palo Alto, CA: Stanford University Press, Second Edition 2006); and W. Reno, 'CSR and Corporate Engagement with Parties to Armed Conflict', in C. Walker-Said and J.D. Kelly, Corporate Social Responsibility?: Human Rights in the New Global Economy (Chicago: The University of Chicago Press Books 2015), at 259-77.

6 According to the Africa Progress Panel, Africa lost US $\$ 63.4$ billion from illicit financial outflows between 2008 and 2010 , of which US $\$ 38.4$ billion was related to mispricing by multinational companies operating in Africa. Africa Progress Panel, Equity in Extractives: Stewarding Africa's Natural Resources for All, Africa Progress Report 2013, Figure 22, at 66.

7 See R. Auty, Sustaining Development in Mineral Economies: The Resource Curse Thesis (Abingdon-on-Thames, UK: Routledge, 1993); M.L. Ross, "The Political Economy of the Resource Curse', 51(2) World Politics (1999) 297-322; and J.D. Sachs and A.M. Warner, 'The Curse of Natural Resources', European Economic Review 45 (2001), at 827-38. 
the illegal exploitation of natural resources is clearly a problem with long historical antecedents and multiple negative impacts in contemporary Africa, thus explaining the desire to criminalize the practice.

A range of complementary initiatives have demonstrated the same desire in recent years, such that this new crime overlaps with a number of related areas of law. If these complementary initiatives underscore the priority the international community attaches to the problem, especially in Africa, they create an interesting and complex overlap with this new offence of 'illicit exploitation of natural resources.' In what follows, we flesh out several of these points of overlap in order to isolate the added normative reach the new offence of Illicit Exploitation offers and to point out opportunities for synergy with pre-existing regulatory initiatives. As we will see, the points of overlap include a range of other criminal offences that might attach to different aspects of resource predation as well as a set of non-criminal schemes that attempt to regulate the same sorts of behaviours.

With respect to overlapping criminal offences, Illicit Exploitation partially overlaps with the war crime of pillage. ${ }^{8}$ In the aftermath of the Second World War, a number of businesspeople were prosecuted for pillaging natural resources during the war, principally because their exploitation was 'illegal' insofar as the true owners of manganese, coal, iron and oil never consented to their appropriation. This exploitation was achieved through a range of different strategies and techniques, but courts invariably concluded that these practices constituted pillage in war. ${ }^{9}$ Pillage appears to be gaining traction as a legal response to the illegal exploitation of natural resources in modern resource wars too. Swiss authorities conducted a formal investigation into one of the largest gold refineries in the world for complicity in pillage a few years ago, ${ }^{10}$

8 For a more extensive analysis of this crime and its relevance for illegal natural resources exploitation, see J.G. Stewart, Corporate War Crimes: Prosecuting the Pillage of Natural Resources (New York: Open Society Justice Initiative Publication 2011); and L.J. van den Herik and D.A. Dam-de Jong, 'Revitalizing the Antique War Crime of Pillage: The Potential and Pitfalls of Using International Criminal Law to Address Illegal Resource Exploitation during Armed Conflict', Vol. 22(3) Criminal Law Forum (2011) 237-73.

9 See e.g. Trials of War Criminals before the Nuremberg Tribunals under Control Council Law No. 10, Vol. IX, the Krupp case (Washington: Government Printing Office 1950), at 1344-5; Trials of War Criminals before the Nuremberg Military Tribunals under Control Council Law No. 10, Vol. XIV, France v. Roechling (Washington: Government Printing Office 1949), at 1113 and 1124 .

10 The investigation was closed in 2015 , because the Swiss prosecutor was unable to proof that the company was aware of the criminal origin of the gold it refined, showing the difficulties in prosecuting companies further up the supply chain. See J.G. Stewart, "The Argos Heraeus Decision on Corporate Pillage of Gold', 19 October 2015, available through http:// jamesgstewart.com/the-argor-heraeus-decision-on-corporate-pillage-of-gold/ (visited 27 September 2016) for a legal analysis of this decision and links to the prosecutor's decision. 
and a Belgian businessman was arrested by the Belgian authorities in 2015 for allegedly collaborating with former Liberian President Charles Taylor and a rebel group in pillaging diamonds from Sierra Leone. ${ }^{11}$ Moreover, in September 2016, the Prosecutor of the International Criminal Court formally published a new prosecutorial strategy, which included a commitment to 'give particular consideration to prosecuting Rome Statute crimes that are committed by means of, or that result in... the illegal exploitation of natural resources. ${ }^{12}$

States have also developed comparable criminal offences through regional agreements to tackle the illicit exploitation of natural resources, notably within the framework of the International Conference on the Great Lakes Region (ICGLR). ${ }^{13}$ Most importantly, a specialized Protocol Against the Illegal Exploitation of Natural Resources was adopted in 2006 as part of the Pact on Security, Stability and Development, which forms the basis for cooperation between the ICGLR Member States. This Protocol aims to promote the development of effective mechanisms to address illegal exploitation of natural resources, to enhance cooperation amongst the ICGLR Member States in this field and to promote harmonization of their national legislations, policies and procedures. ${ }^{14}$ One of the most important tools developed by the ICGLR for this purpose is a regional certification mechanism. ${ }^{15}$ From the perspective of criminal law, however, the most notable aspect of this parallel treaty regime is contained in in Art 12 of the Protocol Against the Illegal Exploitation of Natural Resources, which also contemplates a novel set of domestic offences governing what it calls 'the illegal exploitation of natural resources'. ${ }^{16}$

${ }^{11}$ See https://trialinternational.org/latest-post/michel-desaedeleer/ (visited 8 December 2016). The suspect died in custody on 28 September 2016.

12 Office of the Prosecutor, Policy Paper on Case Selection and Prioritization, para. 41. www.icccpi.int/Pages/item.aspx?name=policy-paper-on-case-selection-and-prioritisation (visited 4 October 2016).

13 The ICGLR is an inter-governmental organization established by the States located in the African Great Lakes region to enhance regional cooperation in the fields of Peace and Security; Democracy and Good Governance; Economic Development and Regional Integration; and Humanitarian and Social Issues. See www.icglr.org for more information.

${ }^{14}$ ICGLR Protocol Against the Illegal Exploitation of Natural Resources, 30 November 2006, Art. 2.

15 See Art. 11 of the Protocol, which was adopted in September 2014. See also www.icglr.org for the certification manual (visited 29 March 2016).

16 Art 12 of the Protocol Against the Illegal Exploitation of Natural Resources reads as follows:

'Each Member State shall ensure that all acts of illegal exploitation of natural resources are offenses under its criminal law. Such acts shall include:

(a) Concluding an agreement to exploit resources, in violation of the principle of peoples' sovereignty over their natural resources; 
Of course, forms of 'illegality' that might inform our understanding of 'illicit' exploitation of natural resources for the purposes of this new crime need not be limited to criminal law. It is perfectly plausible that the new crime of Illicit Exploitation represents the criminalization of a range of regulatory schemes that were never meant to be punished through criminal law beforehand, and on its face, The Protocol purports to do just this. At the global level, for instance, sanctions regimes imposed by the UN Security Council seek to break the link between illegal trade in natural resources on one hand and conflict financing on the other. The Security Council has imposed sanctions in a number of instances, including diamond sanctions against Angola, Sierra Leone and Liberia as well as travel and financial sanctions against individuals and entities involved in illicit natural resources trade in the Central African Republic and the DR Congo. ${ }^{17}$ In order to enhance the effectiveness of its sanctions, the Council has actively relied on several global and regional mechanisms that have been created to address the problem of natural resources financing armed conflicts. ${ }^{18}$

Amongst these are informal mechanisms such as the 2002 certification scheme for rough diamonds developed by the Kimberley Process (KPCS) to tackle the trade in 'conflict diamonds'19 and the 2010 OECD Due Diligence Guidance for Responsible Supply Chains of Minerals from Conflict-Affected

(b) Concluding with state authorities an agreement to exploit natural resources, in violation of the legal and regulatory procedures of the State concerned;

(c) Concluding an agreement to exploit natural resources through corrupt practices;

(d) Concluding an agreement to exploit natural resources that is clearly one-sided;

(e) Exploiting natural resources without any agreement with the State concerned;

(f) Exploiting natural resources without complying with norms relating to the protection of the environment and the security of the people and the staff; and

(g) Violating the norms and standards established by the relevant natural resource certification mechanism.'

17 For a more detailed discussion of these sanctions regimes, see D.A. Dam-de Jong, International Law and Governance of Natural Resources in Conflict and Post-Conflict Situations (Cambridge University Press 2015); and Security Council Report, 'UN Sanctions: Natural Resources', Research Report (2015) No. 4, www.securitycouncilreport.org (last visited i February 2016).

${ }^{18}$ See D.A. Dam-de Jong, 'UN natural resources sanctions regimes: Incorporating market-based responses to address market-driven problems', in L.J. van den Herik (ed.), Research Handbook on UN Sanctions and International Law (Cheltenham Glos, UK: Edward Elgar, 2017).

19 For the purposes of the KPCS, conflict diamonds have been defined as 'rough diamonds used by rebel movements or their allies to finance conflict aimed at undermining legitimate governments, as described in relevant United Nations Security Council (UNSC) resolutions insofar as they remain in effect, or in other similar UNSC resolutions which may be adopted in the future, and as understood and recognized in United Nations General Assembly (UNGA) Resolution 55/56, or in other similar UNGA resolutions which may be adopted in future'. See KPCS Core Document, available at www.kimberleyprocess.com/en/kpcs-core-document (visited 17 March 2016). 
and High-Risk Areas (OECD Guidance) which assists companies in assessing the risks of their mineral purchases to contribute to the commission of international crimes and gross human rights abuses. ${ }^{20}$ In addition, the 2009 Extractive Industries Transparency Initiative (EITI) was created to increase transparency and accountability in the extractive sector by publishing company payments to governments. These are just some of the overlapping non-criminal initiatives that might help in plotting the new crime's significance across a wider set of regulatory initiatives, but at the same time, these initiatives might be relevant in construing the term 'illicit' within this novel offence itself. The relationship between these overlapping criminal offences, complementary regulatory initiatives and the new crime announced within the Protocol is therefore a question that is complex, intriguing and unexplored.

At the same time, this novel crime also raises a number of fundamental concerns, most importantly relating to its scope and specificity. While the provision itself enumerates a limitative list of seven acts that would fall under the crime, the definition of these acts is broad and open to multiple interpretations. At times, there is uncertainty about which overlapping field the reference to 'illicit' exploitation appeals to, but other times interpretative difficulties stem from a failure to set out the scope of the seven sub-offences in terms that will come close to satisfying the demands of a defensible criminal prohibition. In particular, these difficulties pose an inherent danger of overreach and uncertainty that frequently risks compromising the foundational principle of nullum crimen sine lege. In addition, the list omits particular acts that would logically fall under the definition of illicit exploitation of natural resources, most particularly the exploitation of natural resources in contravention of resolutions adopted by the UN Security Council. In what follows, we

20 The OECD Guidance was last revised in April 2016. Strictly speaking, the OECD Guidance is not a global instrument, since it only applies to companies which are based in an OECD member State. Nevertheless, the OECD Guidance has also been incorporated in the regional system of the International Conference for the African Great Lakes Region (ICGLR), it has been endorsed by the UN Security Council and it has resulted in the creation of similar guidelines in non-OECD member States, most importantly the guidelines developed by the Chinese Chamber of Commerce. See www.oecd.org/corporate/mne/mining.htm (visited 30 May 2016); the Lusaka Declaration of the ICGLR Special Summit to Fight Illegal Exploitation of Natural Resources in the Great Lakes Region (2010), para. 12; UN Security Council Resolutions 1952 (2010), para. 8 and 2198, para. 22 on the DR Congo and Resolution 2153 (2014) on Côte d'Ivoire, para. 31; and China Chamber of Commerce of Metals, Minerals and Chemicals Importers \& Exporters, Chinese Due Diligence Guidelines for Responsible Mineral Supply Chains (2015), available at www.cccmc.org.cn/docs/2015-10/ 20151029133501092584.pdf (visited 17 March 2016). 
attempt to plot these and other related concerns while elucidating the scope of the novel offence - as incorporated in Article 28L Bis.

\section{THE SCOPE OF THE PROVISION}

Illicit Exploitation is potentially a very broad term. A wide variety of laws both national and international - govern different aspects of the resource extraction process. Given the absence of official travaux préparatoires for The Protocol, our attempt to identify which norms the offence contemplates is necessarily based on an interpretation of the provision itself within the context of international law generally. In this light, one of the major strengths of Article $28 \mathrm{~L}$ Bis is that it includes a limitative list of acts that constitute 'illicit exploitation' for the purposes of the provision. The definition is thus a welcome attempt to resolve some of the contests about the meaning of the term 'illegal' exploitation in other contexts, ${ }^{21}$ although as we suggest earlier, it still leaves a series of very important questions unanswered. Before we address these intricacies, we pause to consider the overarching chapeau elements that must be satisfied for each of the underlying sub-offences. Structurally speaking, the new crime is vaguely reminiscent of crimes against humanity: it contains an overarching chapeau that operates as a kind of threshold triggering the application of the list of seven sub-offences that are enumerated beneath this threshold. The analysis that follows mimics this structure, commencing

${ }^{21}$ Two of these attempts merit closer attention. Firstly, the UN Panel of Experts on the DR Congo, which had been established by the Security Council to collect information on the illegal exploitation of natural resources in the DR Congo and to analyze the links between natural resources and the continuation of the conflict, opted for a very broad definition of illegal exploitation in its 2001 report. Its definition of 'illegality' hinged on the following four factors related to the rule of law: a violation of sovereignty, specified as all activities that are conducted 'without the consent of the legitimate government'; conducting activities in violation of the existing regulatory framework of the country of operation; activities that are contrary to widely accepted business practices; and activities carried out in violation of international law, including soft law. The term 'exploitation' was similarly defined broadly so as to include 'all activities that enable actors and stakeholders to engage in business in first, secondary and tertiary sectors in relation to the natural resources and other forms of wealth of the Democratic Republic of the Congo'. See Report of the Panel of Experts on the Illegal Exploitation of Natural Resources and Other Forms of Wealth of the Democratic Republic of the Congo, 12 April 2001, UN Doc. S/2001/357, p. 5. The second attempt has been made by the ICGLR for the purposes of its Protocol on Illegal Exploitation of Natural Resources. Art. 1 of the Protocol defines illegal exploitation as 'any exploration, development, acquisition, and disposition of natural resources that is contrary to law, custom, practice, or principle of permanent sovereignty over natural resources, as well as the provisions of this Protocol'. Illegal exploitation as defined by the Panel of Experts and the ICGLR Protocol therefore includes a wide range of aspects of the extraction process, while illegal also refers to a broad range of legal bases. 
with an analysis of the chapeau, then continuing to consider the various suboffences one by one.

By way of preliminary observation, it is important to note that the provision does not formulate distinct objective or subjective requirements for the chapeau itself or for the various sub-offences. ${ }^{22}$ One would normally refer to general provisions concerning the mental elements of crimes for the purposes of The Protocol or detailed definitions of the criminal offences themselves, but alas these are defined nowhere in the instrument. While the Protocol contains an explicit provision on corporate criminal liability, which defines knowledge and intent in the corporate context, ${ }^{23}$ a similar provision for individuals is lacking in the current draft of The Protocol. ${ }^{24}$ Similarly, there is nothing in the Protocol that replicates the clarity and detail of the ICC Elements of Crimes, which seek to provide greater legal clarity to crimes that are broadly defined in the abstract within the ICC Statute itself. To a large extent, the absence of these details undermines The Protocol's creative attempt to criminalize Illicit Exploitation and makes what follows speculative on our part, but we hope that our preliminary analysis provides guidance that may be useful for scholarly debate, judicial interpretation or legislative reform.

\section{A. The Chapeau Requirement of Seriousness}

To recall, the chapeau for the new crime stipulates that 'illicit exploitation of natural resources' means 'any of the following acts if they are of a serious nature affecting the stability of a state, region or the Union. ${ }^{25}$ The chapeau requirement acts as a qualification for all of the seven underlying crimes that make up the umbrella crime of Illicit Exploitation. In other words, the chapeau is an attempt at limiting these offences somehow, given the veritable sea of transactions (minor and grave) it would capture without an initial threshold of this sort. Troublingly, though, the meaning of the terms 'serious nature' and 'affecting the stability' remain entirely without further definition, requiring that courts develop their own understandings in much the same ways as modern

${ }^{22}$ See supra note 1 , for the text of the provision.

23 See Art. 46C of The Protocol, which stipulates that " $[\mathrm{c}$ ]orporate intention to commit an offense may be established by proof that it was the policy of the corporation to do the act which constituted the offense', where a 'policy may be attributed to a corporation where it provides the most reasonable explanation of the conduct of that corporation.' Corporate knowledge on the other hand 'may be established by proof that the actual or constructive knowledge of the relevant information was possessed within the corporation [...] even though the relevant information is divided between corporate personnel.'

24 Art. 46B on individual criminal responsibility does not set out clear mens rea requirements.

25 Emphasis added. 
understandings of crimes against humanity have emerged over the past decades. In what follows, we make a first attempt at plotting several ways of interpreting the chapeau requirement in ways that balance the desire for this offence to address the heart of the problem of Illicit Exploitation without casting such a broad net that the offence is unacceptably over-inclusive.

We take the terms 'affecting the stability of a state, region or the Union' and 'serious nature' as implying separate tests, so deal with each in turn. With respect to the former, it strikes us that a variety of different illicit resource transactions might 'affect the stability of a state, region or the Union' in different ways. Clearly, transactions that have an important impact on the advent or maintenance of warfare affect stability in clear terms. The illicit harvesting of timber in Liberia's civil war as well as the exploitation of Congolese coltan at different points in 'Africa's First World War' had this effect, and to employ an example from outside Africa, the illegal exploitation of Kuwaiti oil by Iraq in 1991 was clearly a factor that affected the stability of the state and region. In each of these scenarios, the transactions had negative impacts on stability in that they produced or sustained war. We see no particular reason, however, to view stability as coterminous with warfare. The term 'stability' might possibility extend to other scenarios, where illicit resource transactions produce political or health crises, major displacement, severe environmental damage or otherwise have serious impacts on the safety of the general population. The difficulty is that without defining the term 'stability,' it is hard to discern whether any of these factors short of warfare will satisfy the chapeau for the crime. We would therefore recommend to reflect upon the scope of the term stability in light of the purpose of the provision. A broad understanding of this term may enhance the possibilities for the Court to play a meaningful role in addressing acts of natural resources exploitation that have serious repercussions for human beings or the environment outside situations of armed conflict or generalized violence.

Unfortunately, the requirement that the illicit transaction be of a 'serious nature' is not markedly clearer either. The illicit trade in diamonds incontestability affected the stability of Angola and the Great Lakes Region over several decades up until the early 1990s, so individuals who were engaged in illicit transactions of a 'serious nature' within the Angolan diamond trade might conceivably be captured by the language in the chapeau. ${ }^{26}$ But which transactions are of a serious nature? Here we see three options:

${ }^{26}$ Although the parallel is not entirely direct, this interpretation of "a serious nature affecting the stability of a state, region or the Union" operates in a manner similar to "a widespread or systematic attack on a civilian population" in the chapeau of Crimes Against Humanity. 
First, one might define 'seriousness' is causal terms, eliminating actors who were making overdetermined causes to the state of instability. ${ }^{27}$ If the defendant was one of very many low-level purchasers of illicit conflict diamonds in Angola, their contribution is less 'serious' than that of actors whose actions were causally necessary for the state of affairs. On this interpretation of seriousness, this offence would be limited to politicians, military leaders, businesspeople and companies that made an important difference to illicit resource markets that destabilized the political system. On this reading, even those who exploited a great deal of illicit resources would not be captured by the offence if they were fungible for a set of other actors who would have done similarly if they had not, emulating the focus on 'those most responsible' in other contexts.

Second, seriousness in this context could mean scale: an individual or corporation involved in the extensive acquisition of illicit Angolan diamonds might undertake acts 'of a serious nature affecting the stability of a state, region or the Union.' This interpretation would exclude single, minor and isolated acts of illicit exploitation, even if they did make some contribution to the terrible state of instability in the region at the time, since these acts would in themselves not be sufficiently serious. Of course, scale itself requires a threshold determination which is sometimes difficult to plot. Does one tally up the entire quantum of diamonds exploited in Angola during the period, ascertain the defendant's relative contribution, and assert jurisdiction if that amount is more than five, ten or twenty-five percent of the whole?

Third, one could interpret 'serious nature' in symbolic terms. If a bank was directly involved in the illicit exploitation of Angolan diamonds, and the role of banks in sustaining illicit resource transactions had never been exposed in Angola or elsewhere, one might consider the responsibility of bankers and their corporations as serious for symbolic reasons. This interpretation is broadest because it would hold regardless of the quantity of the resources illegally acquired or the causal significance of the bank's contribution to the overall state of political stability the trade in diamonds produced for Angola in our hypothetical. Therefore, this option provides prosecutors then courts with considerable discretion.

We express no definitive preference for any one of these interpretative options, although allowing the court an ability to pursue important symbolic

A defendant him or herself need not personally play an important role in the attack; his or her individual crimes must only be adequately connected to it. See ICTY, Prosecutor $v$. Tadić, No. IT-94-1-T, Trial Chamber Judgment of 7 May 1997, para. 649, referred to in C.K. Hall and K. Ambos, 'Article 7', in O. Triffterer and K. Ambos, The Rome Statute of the International Criminal Court: A Commentary (Hart, Third edition 2016), at 165-6.

27 James G. Stewart, Overdetermined Atrocities, 10 Journal of International Criminal Justice 1189-218 (2012). 
cases might allow for a nuanced approach to addressing the illegal exploitation of natural resources provided some of the shortcomings with this provision can be addressed.

\section{B. Acts that Constitute the International Crime}

This section analyses the seven sub-offences included in Article 28L Bis, which are enumerated beneath the chapeau requirement we have just addressed. Structurally, what counts as 'Illicit' for the purposes of Article 28L Bis results either from the conclusion of an agreement (sub-offences a-d) or from the actual exploitation itself (sub-offences e-g). Interestingly however, the provision does not define 'natural resources' or 'exploitation', two concepts that are crucial to defining the scope of the provision. For the purposes of this analysis, we propose to follow the definitions included in the 2006 Protocol Against the Illegal Exploitation of Natural Resources, adopted by the International Conference on the Great Lakes Region. Arguably, these definitions are authoritative, since the text of Article 28L Bis has been taken directly from Article 12 of this Protocol. The 2006 Protocol defines 'natural resources' as 'substances provided by nature that are useful to human beings and have an economic value $[. .$.$] . The major types of natural resources include minerals,$ flora and fauna, fishery products and water ${ }^{28}$ Even though a focus on the economic value and utility of natural resources would be restrictive in other contexts, this definition is appropriate for the purposes of Article $28 \mathrm{~L} \mathrm{Bis,}$ which is exclusively concerned with acts of natural resources exploitation that have an economic dimension. 'Exploitation' for its part is defined as 'any exploration, development, acquisition, and disposition of natural resources', thereby encompassing the whole array of activities from mining to marketing. ${ }^{29}$ The extent to which this definition also encompasses acquisition of natural resources further up the supply chain is not entirely clear, yet it is sufficiently open to accommodate forms of indirect appropriation. We will now proceed to addressing each sub-offence in turn.

1. Concluding an Agreement to Exploit Resources, in Violation of the Principle of Peoples' Sovereignty over Their Natural Resources

The first sub-offence of illicit natural resources exploitation as included in Article $28 \mathrm{~L} \mathrm{Bis} \mathrm{refers} \mathrm{to} \mathrm{the} \mathrm{conclusion} \mathrm{of} \mathrm{an} \mathrm{agreement} \mathrm{to} \mathrm{exploit} \mathrm{natural}$

28 ICGLR Protocol Against the Illegal Exploitation of Natural Resources, 30 November 2006, Art. 1.

29 Ibid. 
resources 'in violation of the principle of peoples' sovereignty over their natural resources'. There are two issues that are important to note from the outset. First, the scope of this provision, which is limited to concluding agreements, implies that the relevant indices for the crime can be found in the terms of the agreement or the circumstances surrounding its conclusion. Thus, the provision would not cover the exploitation of natural resources in contravention of the principle of sovereignty over natural resources without an agreement, which would be covered by other aspects of the offence. ${ }^{30}$ Second, the interpretation of the term 'peoples' is of crucial importance for the scope and addressees of the sub-offence. After all, the term 'peoples' can refer either to the population of a State, to specific groups in a State or to the State itself. ${ }^{31}$ This section addresses both these issues.

The principle of peoples' sovereignty over natural resources can be traced back to the General Assembly resolutions adopted in the 1950s and 1960s formulating a principle of permanent sovereignty over natural resources (PSNR) as well as to Article 1(2) of the 1966 Human Rights Covenants. ${ }^{32}$ However, the principal point of reference for the interpretation of peoples' sovereignty in Article 28L Bis of The Protocol would logically be Article 21 of the African Charter on Human and Peoples' Rights, which is subject to the jurisdiction of the African Court. This provision determines that 'All peoples shall freely dispose of their wealth and natural resources. This right shall be

30 These instances are covered by Art. $28 \mathrm{~L} \mathrm{Bis(e),} \mathrm{which} \mathrm{criminalizes} \mathrm{the} \mathrm{exploitation} \mathrm{of} \mathrm{natural}$ resources without any agreement with the State concerned.

${ }^{31}$ J. Crawford, 'The Right of Self-Determination in International Law', in Alston, P. (ed.), Peoples' Rights, Academy of European Law (Oxford University Press 2001), at 7-67; and R.N. Kiwanuka, "The Meaning of "People" in the African Charter on Human and Peoples' Rights', American Journal of International Law, Vol. 82, No. 1 (1988), at 80-101.

$3^{2}$ See UN General Assembly Resolution 1803 (XVII) on Permanent Sovereignty over Natural Resources, 14 December 1962; 1966 International Covenant on Economic, Social and Cultural Rights (ICESCR), New York, Annex to UNGA Resolution 2200 (XXI) of 16 December 1966, 993 UNTS 3; 1966 International Covenant on Civil and Political Rights (ICCPR), New York, Annex 2 to UNGA Resolution 2200 (XXI) of 16 December 1966, 999 UNTS 171. The principle of permanent sovereignty over natural resources has acquired a firm status in international law. It has been recognized by the International Court of Justice as having customary international law status. See e.g. International Court of Justice, Armed Activities on the Territory of the Congo (Democratic Republic of the Congo v. Uganda), Judgment of 19 December 2005, I.C.J. Reports 2005, para. 244. It has also been inserted in several treaties, especially in the field of international environmental law. For a detailed examination of the principle of permanent sovereignty over natural resources, see N.J. Schrijver, Sovereignty over Natural Resources: Balancing Rights and Duties (Cambridge: Cambridge University Press, 1997); D. Rosenberg, Le Principe de Souveraineté des Etats sur Leurs Ressources Naturelles (Paris, France: Librairie Générale de Droit et de Jurisprudence, 1983); G. Elian, The Principle of Sovereignty over Natural Resources (The Netherlands: Sijthoff \& Noordhoff, 1979). 
exercised in the exclusive interest of the people. In no case shall a people be deprived of it'. Article 21 of the African Charter has proven to be very valuable for the protection of minority rights, ${ }^{33}$ but has also been invoked by States in their relationship with other States. ${ }^{34}$ Therefore, the right of peoples to freely dispose of their natural resources accrues both to States themselves and to groups within a State. The ICGLR Protocol on Illegal Exploitation of Natural Resources defines this relationship more clearly. Article 3 determines that 'Member States shall freely dispose of their natural resources. This right shall be exercised in the exclusive interest of the people. In no case, the populations of a State shall be deprived of it'. ${ }^{35}$ We here discuss some of the principal scenarios that come within the reach of the sub-offence when it is construed in this manner.

First, the sub-offence would potentially cover agreements concluded between armed groups and (foreign) companies that violate the State's right to freely dispose of its natural resources. There are numerous examples in the recent history of Africa concerning armed groups granting concessions to companies to operate mines in territories under their control. For example, the Panel of Experts on Angola revealed in a key report that before the imposition of the diamond sanctions on Angola in 1998, the opposition group UNITA had auctioned off mining permits to foreign companies for the exploitation of mines within UNITA-controlled territory. In addition, the Panel found that UNITA had granted various diamond buyers a licence to operate within the areas under its control in exchange for a commission. ${ }^{36}$ If one considers the principle of sovereignty over natural resources as an attribute of State sovereignty, granting an exclusive authority to the government to exploit natural resources on behalf of the population, these activities would comfortably fit within the current sub-offence. If, on the other hand, one

33 See references to relevant case law below. For a thorough examination of the notion of 'peoples' rights within the African Charter regime, see also R.N. Kiwanuka, "The Meaning of "People" in the African Charter on Human and Peoples' Rights', Vol. 82, No. 1 American Journal of International Law (1988) 80-101.

34 In the Congo-Uganda case, the ICJ based its decision on reparations on Art. 21(2) of the African Charter, which determines that '[i]n case of spoliation the dispossessed people shall have the right to the lawful recovery of its property as well as to an adequate compensation'. International Court of Justice, Armed Activities on the Territory of the Congo (Democratic Republic of the Congo v. Uganda), Judgment of 19 December 2005, I.C.J. Reports 2005, para. 245 .

35 International Conference on the Great Lakes Region, Protocol Against the Illegal Exploitation of Natural Resources, 30 November 2006, Art. 3.

$3^{6}$ See the Report of the Panel of Experts on Violations of Security Council Sanctions against UNITA, UN Doc. S/2000/203, 10 March 2000, paras. 78 and 79. 
adopts a more human rights oriented approach, the ultimate question would be whether the armed group concerned, in this case UNITA, would be considered a representative of the people.

Second, this sub-offence might also cover resource agreements concluded by foreign States or their nationals over resource endowments. In the Armed Activities case before the International Court of Justice, for instance, the DRC contended that Uganda had violated the DRC's sovereignty over its natural resources through illegal exploitation of these resources, including by allowing Congolese rebel groups to trade with Ugandan businesses. ${ }^{37}$ Although the Court concluded that permanent sovereignty over natural resources is a principle of customary international law', it also found that there was nothing suggesting that this principle is 'applicable to the specific situation of looting, pillage and exploitation of certain natural resources by members of the army of a State militarily intervening in another State. ${ }^{38}$ Nonetheless, as Judge Koroma cogently argued in a separate opinion in that case, 'these rights and interests [permanent sovereignty over natural resources] remain in effect at all times, including during armed conflict and occupation. 39 Thus, the factual allegations the ICJ addressed in the DRC $v$. Uganda case might also satisfy this limb of the offence of Illicit Exploitation.

Third, agreements by state officials to the detriment of the State's population might also fall within the purview of the sub-offence. Africa has suffered several kleptocratic rulers who divert natural resources revenues from the national budget for their own personal gain through strong man politics and patronage networks. ${ }^{40}$ Relevant examples include Sese Seko Mobutu, the former president of Zaïre, currently the DR Congo, and Charles Taylor, the former president of Liberia, who were both accused of using the country's natural resources for their own personal enrichment. ${ }^{41}$ These activities - at least in as far as they concern the underlying agreements concluded with companies allowing for the diversion of revenues - would likely be captured

37 See International Court of Justice, Armed Activities on the Territory of the Congo (Democratic Republic of the Congo v. Uganda), Judgment of 19 December 2005, I.C.J. Reports 2005, para. $226-9$.

$3^{8}$ Ibid., para. 244 .

39 Ibid., Declaration of Judge Koroma, para. 11.

$4^{\circ} \mathrm{W}$. Reno, Warfare in Independent Africa (Cambridge, UK: Cambridge University Press 2011).

${ }^{4}$ See e.g. for the DR Congo, Office of the High Commissioner for Human Rights, Report of the Mapping Exercise Documenting the Most Serious Violations of Human Rights and International Humanitarian Law Committed within the Territory of the Democratic Republic of the Congo Between March 1993 and June 2003 (2010), p. 351; and for Liberia, Report of the Panel of Experts Pursuant to Security Council Resolution 1343 (2001), Paragraph 19, Concerning Liberia, UN Doc. S/2001/1015, paras. 309-50. 
by the novel crime of illicit exploitation of natural resources as formulated in Article 28L Bis(a) of The Protocol, ${ }^{42}$ since the 'peoples' sovereignty over natural resources was violated by their political leaders. In this sense, the offence is possibly a backdoor solution for the failure to criminalize kleptocracy itself. ${ }^{43}$

Fourth, the sub-offence might also be relevant to concession agreements that violate the rights of indigenous peoples over land. Even though there is still considerable controversy about the precise scope of the rights of indigenous peoples over their lands and the natural resources found therein, ${ }^{44}$ there is growing recognition that these peoples' special relationship with their lands requires some form of protection, which would impact on States' right to regulate natural resources exploitation. The Ogoni case brought before the African Commission provides a relevant example. The Commission considered in this case that the failure of the Nigerian government to regulate and monitor the activities of private actors benefitting from concessions on the land inhabited by the Ogoni people constituted a violation of the State's obligation to act in the interest of the people when exercising its right to freely dispose of its natural resources, notably because of the detrimental effects of the corporate activities on the livelihood of the people of Ogoniland. ${ }^{45}$ There is also a growing body of case law by other human rights bodies dealing with

$4^{2}$ Concluding agreements for personal enrichment would also be partly captured by Art. 28L Bis (c), dealing with corrupt practices. However, this provision is limited to using corruption as a means to conclude contracts, which, potentially, leaves out advantages that are derived from the contract itself. This issue is examined under (c).

43 S. B. Starr, Extraordinary Crimes at Ordinary Times: International Justice Beyond Crisis Situations, SSRN Scholarly Paper ID 934470 (Social Science Research Network). However, note that Art. 46A Bis of The Protocol determines that 'No charges shall be commenced or continued before the Court against any serving AU Head of State or Government, or anybody acting or entitled to act in such capacity, or other senior state officials based on their functions, during their tenure of office'.

44 See A. Xanthaki, Indigenous Rights and United Nations Standards: Self-Determination, Culture and Land, (Cambridge University Press 2007); and N.J. Schrijver, 'Unravelling State Sovereignty? The Controversy on the Right of Indigenous Peoples to Permanent Sovereignty over their Natural Wealth and Resources', in Boerefijn, I. \& Goldschmidt, J. (ed.), Changing Perceptions of Sovereignty and Human Rights: Essays in Honour of Cees Flinterman (Cambridge, UK: Intersentia 2008), at 85-98. See also the final report of the Special Rapporteur of the Commission on Human Rights, Mrs. Erica Daes, on Indigenous peoples' permanent sovereignty over natural resources, UN Doc. E/CN.4/Sub.2/2004/30 of 13 July 2004 and its addendum, UN Doc. E/CN.4/Sub.2/2004/3o/Add.1 of 12 July 2004.

45 Decision of the African Commission on Human \& Peoples' Rights Regarding Communication 155/96, The Social and Economic Rights Action Center and the Center for Economic and Social Rights v. Nigeria, ACHPR/COMM/Ao44/1, paras. 55-8. The relevant provision is Art. 21 of the African Charter on Human and Peoples' Rights. 
the rights of indigenous peoples over land in relation to concessions concluded by governments, indicating that there is an obligation for States to consult indigenous peoples on natural resources projects. ${ }^{4}$

Notwithstanding these developments, the question can be raised whether the actual conclusion of a concession agreement between the State and a (foreign) company violates the sovereignty of indigenous peoples over their natural resources. Most of the relevant cases deal with States' obligations in relation to secondary rights, for example to obtain prior and informed consent by indigenous peoples or, as in the Ogoni case, to regulate the environmental and social aspects of natural resources exploitation. In addition, whether violations of the rights of indigenous peoples would reach the threshold established in the chapeau is debatable. Arguably, instances in which agreements affecting the rights of indigenous peoples would have an actual or potential impact on the stability of the State itself would be exceptional. For these reasons, it is uncertain if and to what extent the sub-offence would cover agreements concluded by the State to the detriment of indigenous peoples.

2. Concluding with State Authorities an Agreement to Exploit Natural Resources, in Violation of the Legal and Regulatory Procedures of the State Concerned

The second sub-offence of 'illicit exploitation of natural resources' aims to criminalize the conclusion of contracts with state officials in violation of procedures set out in relevant national legislation. Some may argue that this provision is unduly onerous. Whether one should hold an investor criminally responsible for concluding an agreement contrary to domestic law, when this agreement is concluded with state authorities as the guardians of their own laws and regulations is disputable. This concern is all the more valid if one considers that the provision is formulated broadly. It refers generally to domestic 'legal and regulatory procedures'. Does this mean that any violation of these procedures would be criminal for the purposes of this provision? Or would the provision only apply to laws and regulations that aim to protect important values of the host State? In addition, should the African Court be allowed to scrutinize the policies of sovereign States, which may have good reasons to exempt a project from its regulatory procedures? Notwithstanding

$4^{6}$ See e.g. the Inter-American Court of Human Rights, Case of the Saramaka People v. Surinam, Judgment of 28 November 2007; Inter-American Court of Human Rights, The Kichwa people of Sarayaku v. Ecuador, Judgment of 26 July 2012; Human Rights Committee, Apirana Mahuika et al. v. New Zealand, Communication No. 547/1993, 15 November 2000. 
the fact that the chapeau can play an important role in limiting the instances to which the sub-offence applies, there is a need to define the elements of the current sub-offence more clearly. Current case law by international investment tribunals regarding the legality of investments may be a helpful reference in this regard, ${ }^{47}$ but mostly the issue is one that warrants far greater thought. The principal question would be what type of acts the provision aims to target: would it be confined to situations where investors collude with State authorities acting ultra vires or would it also encompass other situations? In the following, two examples will be provided to demonstrate the types of situations that are potentially covered by the sub-offence.

A Nigerian case provides a first relevant example. This case involved a contract concluded by Shell and Eni with the Nigerian government to exploit a major oil field off the coast of Nigeria. The Nigerian government allegedly acted as a middle-man for the Nigerian company Malabu, said to be owned by the former oil minister Dan Etete. ${ }^{4}$ After the conclusion of the deal, the money was allegedly transferred to Malabu and diverted to Etete's personal bank account. ${ }^{49}$ In 2014, the Nigerian House of Representatives called on the Nigerian government to cancel the deal, describing it as 'contrary to the laws of Nigeria. ${ }^{50}$ If Shell and Eni knew that the Nigerian government acted only as a middle-man, ${ }^{51}$ this incident could arguably come within the purview of the current sub-offence, although we reiterate the complexities of discerning whether particular transactions meet the chapeau threshold and again highlight the absence of any indications about the requisite mental elements for these crimes.

Liberia offers a slight variation of the same offence. A 2013 audit report commissioned by the staff of the Liberian Extractive Industries Transparency

47 See R. Dolzer and C. Schreuer, Principles of International Investment Law (Oxford: Oxford University Press, Second edition, 2012), at 92-7 for examples of cases where arbitral tribunals denied jurisdiction on these grounds.

$4^{8}$ See Global Witness, Shell and Eni's Misadventures in Nigeria: Shell and Eni at risk of losing enormous oil block acquired in corrupt deal, November 2015, available online at www.globalwitness.org/en/campaigns/oil-gas-and-mining/shell-and-enis-misadventures-nigeria/ (visited 12 May 2016).

49 See Global Witness, Shell and Eni's Misadventures in Nigeria: Shell and Eni at risk of losing enormous oil block acquired in corrupt deal, November 2015, available online at www.globalwitness.org/en/campaigns/oil-gas-and-mining/shell-and-enis-misadventures-nigeria/ (visited 12 May 2016).

50 Ibid., p. 3 .

${ }^{51}$ This is currently being investigated in Nigeria and Italy, with the cooperation of the Dutch authorities. See E. Sylvers and S. Kent, 'Shell Under Investigation in Italy over Nigerian Oil Deal: Anglo-Dutch Oil Giant Drawn into Corruption Probe that has Dogged Italy's Eni', The Wall Street Journal 30 March 2016. 
Initiative (LEITI) to investigate 68 contracts concluded by the Liberian authorities between 2009 and 2011 determined that 90 per cent of these contracts violated the provisions of relevant mining and forestry laws. ${ }^{52}$ Although it is not entirely clear whether the Liberian cases would in themselves meet the threshold set by the chapeau of Art. $28 \mathrm{LBis}$, it is important to consider these in light of Liberia's recent history. It was only a decade ago that major scandals in the Liberian mining sector were considered to constitute such a threat to the Liberian peace process that international donors initiated an intrusive yet fairly successful programme, the Governance and Economic Management Assistance Programme (GEMAP), to improve public administration, focusing inter alia on concession procedures. ${ }^{53}$ With the caveats we mention throughout, these too might violate this limb of the new offence enshrined within The Protocol.

\section{Concluding an Agreement to Exploit Natural Resources through Corrupt Practices}

This sub-offence seeks to criminalize a widespread phenomenon, which severely diminishes the chances that African peoples will benefit from their natural resource endowments. Corruption can take several forms in relation to natural resources. In addition to the diversion of revenues obtained from exploration and exploitation contracts, another commonly used method is the undervaluation of public natural resources deposits. The 2013 Africa Progress Report concluded, for example, that assets in the mining industry in the DR Congo were sold on average at one-sixth of their estimated value. ${ }^{54}$ Even though the Panel focused on the undervaluation itself and did not investigate allegations of corruption, it did signal that corruption would be one of the factors explaining the undervaluation. ${ }^{55}$ Significantly, this sub-offence would

${ }^{52}$ Final Report for the Liberia Extractive Transparency Initiative (LEITI) Post Award Process Audit, conducted by Moore Stephens LLP, May 2013, available online at www.leiti.org.lr/ uploads/2/1/5/6/21569928/leiti_post_award_process_audit_final_report.pdf (visited on 24 May 2016).

53 See e.g. R. Dwan and L. Bailey, Liberia's Governance and Economic Management Assistance Programme (GEMAP), A joint review by the Department of Peacekeeping Operations' Peacekeeping Best Practices Section and the World Bank's Fragile States Group, May 2006.

54 Africa Progress Panel, Equity in Extractives: Stewarding Africa's Natural Resources for All, Africa Progress Report 2013, at 56. The Panel based its findings on five deals concluded between 2010 and 2012.

55 Ibid. See also Global Witness, Digging in Corruption: Fraud, Abuse and Exploitation in Katanga's Copper and Cobalt Mines, July 2006, at 35-8 for earlier examples. 
criminalize corruption in these circumstances, again under the umbrella of Illicit Exploitation.

For definitional purposes, the current sub-offence should be read in conjunction with Article 28I of The Protocol, which criminalizes acts of corruption 'if they are of a serious nature affecting the stability of a state, region or the Union'. The term 'corruption' in Article 28I is defined so as to include inter alia the offering or acceptance of financial benefits or other advantages, by or to public officials, persons directing or working for private entities or other persons in a position to exert improper influence on the decision-making process, whether for their own advantage or for the advantage of third persons. The provision covers acts of bribery, embezzlement, illicit enrichment and concealment. It thereby largely follows the principal categories of corruption established in the 2004 UN Convention Against Corruption and complements its provisions on domestic criminalization. ${ }^{56}$ Borrowing this provision from elsewhere in The Protocol is therefore very appropriate in interpreting this limb of Illicit Expropriation.

If this reading is accurate, however, this third limb of the definition of illicit exploitation of natural resources is somewhat duplicative of acts criminalized elsewhere in The Protocol. In other words, what would be the added value of including a separate sub-offence under the heading 'illicit exploitation of natural resources' allowing for the prosecution of corrupt practices as a means to conclude an agreement to exploit natural resources if these corrupt practices can also be prosecuted as acts of corruption in their own right? From this perspective, the inclusion of the current sub-offence in The Protocol predominantly has symbolic value, in the sense that it emphasizes that all forms of financial or other incentives used to persuade a person in a position of power to conclude a contract are criminal.

\section{Concluding an Agreement to Exploit Natural Resources That Is Clearly One-Sided}

This sub-offence is worded very vaguely and can only be properly understood with reference to the French authentic version of the text, which criminalizes

${ }^{56}$ It should however be noted that in some respects The Protocol adopts a narrower definition of corruption than the UN Convention. The Protocol, for example, restricts embezzlement to the redirecting of State funds by public officials, thereby using a narrower construction than Art. 17 of the UN Convention, which applies to both public and private funds entrusted to public officials. Also, The Protocol does not contain an equivalent to Art. 22 of the UN Convention, regarding embezzlement by persons directing or working for private companies of funds or any other thing of value entrusted to them. 
'la conclusion par fraude ou par tromperie d'un contrat d'exploitation des ressources naturelles'. ${ }^{57}$ According to the French text, the sub-offence would apply to the conclusion of contracts by means of fraud or deception. We recommend following this definition, since it is much more precise than the reference to agreements that are 'clearly one-sided' in the English text. Upon this reading of the text, the current sub-offence would apply to cases of intention to deceive (state) authorities or business partners when negotiating contracts. This can relate, for example, to misrepresentation by the investor of its financial capabilities or concealment of the company's true ownership (shell companies), provided of course that these forms of misrepresentation are of such a serious nature as to actually or potentially affect national stability. State officials may also be liable for the offence if they undertake similar practices.

Other examples would relate to tax avoidance schemes that would deprive the host state of substantial tax revenues. ${ }^{5}$ One way is the deliberate mispricing of assets in cross-border intra-company transactions. ${ }^{59}$ This practice can be avoided through the inclusion of express provisions in investment contracts concluded between the host State and the investor stipulating that transfer pricing should be based on the arm's length principle, i.e. that it should reflect actual market value. ${ }^{6 \circ}$ Arguably, the prosecution of these practices would send a strong signal to companies that they should refrain from creating loopholes in the system that produce grossly inequitable agreements in developing countries. Nevertheless, whether this issue fits squarely within the ambit of this particular offence is a question that courts and scholars will have to address in greater depth in the future.

\section{Exploiting Natural Resources without Any Agreement with the State Concerned}

Read in conjunction with the chapeau, this limb is by far the most appropriate aspect of Illicit Exploitation for addressing the trade in 'conflict resources.'

57 See Protocole Portant Amendements au Protocole Portant Statut de la Cour Africaine de Justice et des Droits de l'Homme, African Journal of International Criminal Justice (1) 1 (2014), at 185 .

$5^{8}$ See for examples Environmental Law Alliance Worldwide, Natural Resource Contracts: A Practical Guide, November 2013, available online at www.elaw.org/system/files/Natural_ Resource_Contracts_Guide.pdf (visited on 26 May 2016), at 29-33.

59 Africa Progress Panel, Equity in Extractives: Stewarding Africa's Natural Resources for All, Africa Progress Report 2013, at 65. See also the OECD Transfer Pricing Guidelines for Multinational Enterprises and Tax Administrations 2010 (OECD Publishing 2010), DOI: http://dx.doi.org/10.1787/tpg-2010-en.

6o See Ibid. 
The practice is often dependent on military and political elites who arrange the exploitation and benefit from its proceeds. In addition, businesspeople and corporations often play an important role in perpetuating these practices, either by procuring natural resources from armed groups or by exploiting natural resources under the control of armed groups. ${ }^{61}$ Article $28 \mathrm{~L}$ Bis $(\mathrm{e})$ could therefore provide a legal basis for prosecuting those involved in the exploitation of conflict resources, whether this concerns senior members of armed groups, corporations or their representatives.

However, there are important reasons to reconsider the formulation of this limb, since it seems to portray the State as the only authority entitled to alienate natural resources. We recommend interpreting the reference to 'agreement with the State' as requiring permission from an entity which has the authority to dispose of the natural resources concerned. There are two important reasons for opting for this interpretation. First, an exclusive focus on the State as the only authority entitled to conclude agreements over the exploitation of natural resources would have the effect of criminalizing companies for doing business with private concessionaires or mine owners possessing a valid legal title. Title in natural resources is regulated differently from one jurisdiction to the next. ${ }^{62}$ Even in instances where States are the owners of natural resources within their territory, they are perfectly capable of passing this title on to private owners. Clearly, the drafters of this provision never meant to criminalize cases where a businessperson, for instance, purchases natural resources from a company that enjoyed title in those resources, even though this is what the language of the provision suggests.

In addition, especially in the midst of a full-blown internal armed conflict, it is not always clear which entity is entitled to formally represent the State and therefore has the right to dispose of its natural resources. Even though there is

61 For examples of corporate involvement in the exploitation of conflict resources, see e.g. the Report of the Panel of Experts on Violations of Security Council Sanctions against UNITA, UN Doc. S/200o/203, 10 March 2000, paras. 78, 79, 87-93; the Final Report of the Monitoring Group on Angola, UN Doc. S/200o/1225, in particular, paras. 154-61; and the Report of the Panel of Experts appointed pursuant to Security Council Resolution 1306 (2000), paragraph 19, in relation to Sierra Leone, UN Doc. S/200o/1195, December 2000.

62 Of the roughly three models governing natural resources ownership across national jurisdictions, only one (the concession system) vests ownership of natural resources in the state. In this system, it is the State that has the exclusive authority to grant rights to search for, extract, process, and sell these resources. Alternative systems are the claims system, which confers ownership of minerals on anyone who discovers the deposit, subject only to certain formalities; and the accession system, which vests ownership in natural resources to the owner of the land where the resources are found. See J.G. Stewart, Corporate War Crimes: Prosecuting the Pillage of Natural Resources (New York: Open Society Justice Initiative Publication 2011), at 40. 
a presumption in international law in favour of the incumbent government, ${ }^{6}$ there may be circumstances in which other entities have competing or even better claims. Arguably, a right to exploit natural resources can accrue to armed groups who are in effective control of parts of the State territory, as long as the revenues obtained from the exploitation of natural resources are used for the benefit of the local population. ${ }^{64}$ By contrast, there may be circumstances in which the incumbent government can no longer be deemed to be entitled to dispose of the State's natural resources. To illustrate, the UN Security Council imposed an asset freeze on the Libyan authorities in 2011, including on Libya's national oil company as a 'potential source of funding for [Gaddafi's] regime'. ${ }^{65}$ In light of these shortcomings, we recommend amending the provision by replacing 'States' with 'owners' or for courts to interpret the provision in this fashion.

\section{Exploiting Natural Resources without Complying with Norms Relating to the Protection of the Environment and the Security of the People and the Staff}

This sixth sub-offence is a significant departure from the preceding suboffences, in the sense that it is directly concerned with the protection of values other than those related to ownership. Whereas earlier aspects of Illicit Exploitation approximated to theft, this sub-offence instead focuses on the effects of resource exploitation on the environment and human beings. A strict reading of the provision would confine the sub-offence to instances that satisfy

$6_{3}$ See H. Lauterpacht, Recognition in International Law, (first published in 1947; 2013 paperback edition, Cambridge University Press), at 94 in relation to the recognition of governments more generally; and D.A. Dam-de Jong, 'Armed Opposition Groups and the Right to Exercise Control over Public Natural Resources: A Legal Analysis of the Cases of Libya and Syria', Netherlands International Law Review 62(1), at 3-24 in relation to natural resources exploitation.

${ }^{64}$ See W. Reno, 'CSR and Corporate Engagement with Parties to Armed Conflict', in C. WalkerSaid and J.D. Kelly, Corporate Social Responsibility?: Human Rights in the New Global Economy (Chicago, US: The University of Chicago Press Books 2015), at 259-77; J.G. Stewart, Corporate War Crimes: Prosecuting the Pillage of Natural Resources (Open Society Justice Initiative Publication 2011), at 58-62; and D.A. Dam-de Jong, 'Armed Opposition Groups and the Right to Exercise Control over Public Natural Resources: A Legal Analysis of the Cases of Libya and Syria', Netherlands International Law Review 62(1), at 3-24.

65 See UN Security Council Resolution 1973 (2011), 17 March 2011, para. 19 and Annex II. On 24 June 2011, the Sanctions Committee extended the assets freeze to a subsidiary of the Libyan National Oil Corporation. See in this regard the following press release: 'Security Council Committee Concerning Libya Adds Names of Individuals and Entities to Its Travel Ban and Assets Freeze List', UN Doc. SC/10302, 28 June 2011. 
both elements: the release of toxic substances, for example, will harm the environment and will also affect the security of the people and the staff. There are, however, also instances where either the environment is harmed or the security of the people and/or the staff are endangered. We presume that these instances are also covered by the sub-offence, notwithstanding the use of the word 'and' in The Protocol.

The first issue that this limb may address is large-scale environmental pollution caused by the mining industry, provided this would affect the stability of the State. In this sense, it also aligns with current discussions regarding the introduction of environmental crimes in international criminal law. ${ }^{66}$ Environmental pollution would particularly affect the stability of the State if it would harm vulnerable communities, who are dependent on the environment for their livelihood, or when the pollution would cause serious diseases amongst the population, as these effects would enhance grievances amongst the population and thereby affect stability negatively. One of the most well-known examples reaching this threshold is the environmental pollution caused by oil spills in the Nigerian Niger delta, which have seriously contaminated the fragile wetlands and their rich biodiversity, depriving the local population of its basic means of subsistence and exposing them to major health risks. ${ }^{67}$ Importantly, this pollution also had serious repercussions for the security in the Niger delta. ${ }^{68}$

The provision may also address concerns arising from security measures to protect the operations of extractive companies, especially when these operations are carried out in conflict-prone or conflict-torn regions. Mining companies often use security forces to protect their interests, including State forces and private security firms. Sometimes clashes occur between those security

66 S. Freeland, Addressing the Intentional Destruction of the Environment during Warfare under the Rome Statute of the International Criminal Court (Intersentia 2015); and S. Jodoin and M. Cordonier Segger, Sustainable Development, International Criminal Justice, and Treaty Implementation (Cambridge, UK: Cambridge University Press 2013).

${ }^{67}$ See UNEP, Environmental Assessment of Ogoniland (2011), available online at http://postconflict.unep.ch/publications/OEA/UNEP_OEA.pdf (visited 1 June 2016).

68 The environmental pollution caused by the oil spills has been the subject of several legal procedures, including before the African Commission against the Nigerian government and before Dutch courts against Shell. See the Decision of the African Commission on Human \& Peoples' Rights Regarding Communication 155/96, The Social and Economic Rights Action Center and the Center for Economic and Social Rights v. Nigeria, ACHPR/COMM/Ao44/1; District Court The Hague, Oguru-Efanga/Shell, Judgment of 30 January 2013, ECLI:NL: RBSGR:2013:BY9850; District Court The Hague, Dooh/Shell, Judgment of 30 January 2013, ECLI:NL:RBSGR:2013:BY9854; and District Court, Akpan/Shell, Judgment of The Hague 30 January 2013, ECLI:NL:RBSGR:2013:BY9854. The case is currently in appeal. In addition, Shell settled a case out of court that was filed before the English court. 
firms and the local population, especially in reaction to popular protests against the company's operations. By way of example, clashes allegedly occurred in Tanzania in 2011, when local villagers tried to enter a gold mine operated by a British company in protest to their operations. The security forces were accused of having used excessive violence against the population, including killings, severe beatings and rape. The subsequent lawsuit filed by the villagers in the UK court was settled out of court in early 2015. ${ }^{69}$ In addition to incidents involving local communities, companies have also been accused of using excessive force against their own staff, sometimes in cooperation with local or State authorities. A well-known example is the incident at the Marikana platinum mine in South Africa in August 2002, when 34 workers who were striking to improve their working conditions were allegedly killed by the police. $^{70}$ This incident led to a series of strikes throughout the country, potentially bringing the 'Marikana massacre' within the ambit of the chapeau. These are just some examples of violence used by companies or State authorities against local communities and staff, which could be addressed by the current provision, provided one adheres to a broader reading of the sub-offence.

Lastly, the sub-offence could cover serious violations of fundamental safety and health norms, such as exposing employees to dangerous substances or exploiting natural resources without taking any precautions to prevent serious accidents, such as explosions. Here again, it is unclear what violations of these norms would reach the threshold set by the chapeau. Would the explosion of a single mine affect the stability of a State, if it is symptomatic of a broader pattern of violation of safety standards? To draw on a famous example from outside both the resource sector and Africa, in 1997, the accounting firm Ernst \& Young completed an audit of a shoe manufacturing plant in Vietnam for Nike. The report indicated that there is no adequate water reserved for comfort use of workers', dust and toxic fumes in parts of the plant 'exceeded the standard from 6 to 177 times', and 'there are 128 employees (77.57\%) getting respiratory disease and 7 employees $(4.24 \%)$ getting heart disease. ${ }^{71}$ With the caveats about the chapeau requirement and the need to prove mental elements that are not defined in The Protocol, a repetition of similar

69 Business \& Human Rights Resource Centre, African Barrick Gold lawsuit (re. Tanzania), available online at http://business-humanrights.org/en/african-barrick-gold-lawsuit-re-tanzania (visited on 2 June 2016).

70 See S. Adelman, 'The Marikana Massacre, the Rule of Law and South Africa's Violent Democracy', (2) Hague Journal on the Rule of Law 7 (2015) 243-62.

${ }^{71}$ Ernst \& Young Environmental and Labor Practice Audit of the Tae Kwang Vina Industrial Ltd. Co., Vietnam, 13 January 1997. Available online at www.corpwatch.org/article.php?id=2488\& printsafe $=1$. Last visited 7 December 2016 . 
practices in the resource sector in Africa might violate this limb of The Protocol's definition of Illicit Exploitation.

A final issue that needs to be clarified relates to the term 'norms'. The reference to 'norms' in the provision is open-ended and begs the question of what types of norms would be covered. Would these include soft law norms, such as ILO standards, ISO standards for environmental protection, the OECD Guidelines for Multinational Companies or the Voluntary Principles on Security and Human Rights? Since the provision addresses the responsibility of private companies in addition to state actors, it may be assumed that norms and standards developed by non-binding instruments and national law would be the principal benchmarks against which to assess the legality of their behaviour. This does not have to be problematic from the perspective of legal certainty, as long as these instruments provide sufficiently detailed guidance to companies against which to assess their behaviour. However, on a more fundamental level, one may wonder if it is appropriate to elevate so-called 'voluntary' instruments to the level of binding norms by criminalizing the breach of their provisions.

7. Violating the Norms and Standards Established by the Relevant Natural Resource Certification Mechanism

This limb of the Illicit Exploitation offence criminalizes the violation of norms and standards set by natural resources certification mechanisms. Currently, there are two important resource certification mechanisms in place in Africa. These are the Kimberley Process Scheme for the Certification of Rough Diamonds (KPCS) and the ICGLR Regional Certification Mechanism for tin, tantalum, tungsten and gold (3TG). We briefly consider both of these certification schemes, highlighting the very significant implications that arise from the quick criminalization of regulatory regimes that were sometimes created for states, frequently intended as soft law, and seldom given the sort of precision that might ground criminal liability.

The KPCS requires States to adopt a system of internal controls designed to eliminate conflict diamonds from shipments of rough diamonds imported into or exported from their territory. ${ }^{72}$ For this purpose, participants must designate Importing and Exporting Authorities, ensure that rough diamonds are imported and exported in tamper-proof containers, adopt appropriate legislation to implement and enforce the Certification Scheme, and collect, maintain and

${ }^{22}$ Kimberley Process Certification Scheme, available online at www.kimberleyprocess.com/en/ kpcs-core-document (visited 10 May 2016), Sect. IV(a). 
exchange official production, import and export data with other participants. ${ }^{73}$ The KPCS constitutes soft law, formulating non-binding 'minimum requirements' for States to implement in their domestic systems. The sudden criminalization of violations of this scheme raises a series of important questions: (a) which aspects of the KPCS fall within the scope of the crime; (b) can non-state actors also violate the 'norms and standards' of the KPCS for the purpose of Article $28 \mathrm{~L} \mathrm{Bis}(\mathrm{g})$ of The Protocol even though the scheme addresses States exclusively; ${ }^{74}$ and (c) have states fully understood that the ways in which violations of the KPCS were just transformed into supranational crimes?

The certification mechanism developed by the ICGLR is the second important regulatory scheme. This mechanism introduces a system of controls aimed at guaranteeing that minerals exported from the ICGLR are conflictfree. ${ }^{75}$ The system encompasses certification for mines to attest that they are conflict-free and meet certain minimum social standards. ${ }^{76}$ In addition, it introduces a chain of custody tracking system for minerals to prevent any sort of support to armed groups throughout the supply chain to the point of export and, lastly, it comprises the certification of mineral exports. This process is monitored by government officials and third party audits, while regional databases for the designated minerals seek to bring greater transparency in the mineral flows. ${ }^{77}$ Contrary to the KPCS, the ICGRL certification mechanism does contain direct obligations for private actors, such as processors,

73 Kimberley Process Certification Scheme, Sects. IV(b)-(f).

74 If so, this sub-offense could cover some of the major issues which have hampered the implementation of the KPCS since its very establishment, notably the issuing of fraudulent certificates by state authorities allowing blood diamonds to enter the legal market See www.kimberleyprocess.com/en/enforcement (visited on 14 October 2016).

75 'Conflict-free' is defined as 'free from support for non-state armed groups or public or private security forces who: (a) "illegally control mine sites or otherwise control transportation routes, points where minerals are traded and upstream actors in the supply chain"; (b) "illegally tax or extort money or minerals at points of access to mine sites, along transportation routes or at points where minerals are traded"; and/or (c) "illegally tax or extort intermediaries, export companies or international traders'. See the ICGLR Regional Certification Mechanism (RCM) - Certification Manual, available online at www.oecd.org/investment $/ \mathrm{mne} / 49111368$ .pdf (visited 10 May 2016), at 4 .

$7^{6}$ These minimum standards seek to eliminate “"any forms of torture, cruel, inhuman and degrading treatment"; (ii) "any forms of forced or compulsory labour, which means work or service which is exacted from any person under the menace of penalty and for which said person has not offered himself voluntarily"; (iii) "the worst forms of child labour"; (iv) "other gross human rights violations and abuses such as widespread sexual violence"; and, (v) "war crimes or other serious violations of international humanitarian law, crimes against humanity or genocide".' See the ICGLR Regional Certification Mechanism (RCM) - Certification Manual, at 4 .

77 See Ibid. 
comptoirs, smelters and other exporting entities, the latter defined as a 'company, cooperative, individual or other entity that exports Designated Minerals from a Member State. ${ }^{7}$ Relevant obligations include an obligation to refrain from purchasing minerals from uncertified mines and an obligation to ensure that other actors upstream in the supply chain, i.e. those actors from which the minerals are purchased, act in compliance with the relevant standards set by the mechanism. ${ }^{79}$ Since these obligations are numerous, sometimes procedural and not explicitly specified, we believe that this sub-offence is overly broad and requires clarification.

More generally, it is questionable whether the violation of "norms and standards' that are part of soft law should be recognized as an international crime at all. Even as far as these norms and standards have been included in domestic legislation, the transformation of these non-criminal "norms and standards' into a supranational criminal offence may strike some as controversial if not harsh. The problem with the norms and standards included in certification mechanisms is that, apart from having been drafted as best practices in the industry rather than criminal offences, they are continually subject to change. Both shortcomings are problematic from the perspective of providing the legal certainty required for a serious criminal offence. Thus, reformulating this sub-offence as a separate crime, moving away from 'norms and standards', and focusing on the issue of due diligence obligations for companies may better delimit this offence. The OECD Due Diligence Guidance for Responsible Supply Chains of Minerals from Conflict-Affected and High-Risk Areas can be a useful tool in this respect, since it provides a clear five-step framework for companies to exercise due diligence. Even here, though, it would be highly advisable to translate these broad policies into terms typical for criminal offences, including by stipulating the crime's objective and subjective elements explicitly.

\section{CONCLUSION}

The crime of illicit exploitation of natural resources, as included in The Protocol, is highly innovative. It provides new opportunities to address grave

$7^{8}$ ICGLR Regional Certification Mechanism (RCM) - Certification Manual, at 6.

79 Ibid., at 30. The latter obligation amounts to a due diligence obligation as set out under the OECD Due Diligence Guidance for Responsible Supply Chains of Minerals from ConflictAffected and High-Risk Areas. See OECD, OECD Due Diligence Guidance for Responsible Supply Chains of Minerals from Conflict-Affected and High-Risk Areas (Paris, France: OECD Publishing, Third Edition, 2016), available online at http://dx.doi.org/10.1787/9789264252479en (visited on 10 May 2016). 
injustices related to the exploitation of natural resources as well as to bolster the abilities of African States to use their natural resource wealth for the benefit of their respective peoples. At the same time, the provision as currently formulated is unsatisfactory in several dimensions. In some regards, the crime overcriminalizes a whole raft of regulatory regimes no one previously thought gave rise to criminal responsibility. In other instances, a strict reading of the Protocol would result in the criminalization of perfectly legal acts. Elsewhere, there is the problem of overlap, both within the provision and in relation to other provisions included in The Protocol. Overall, the absence of any mention of objective or subjective elements capable of proving the offence transgress basic principles in the criminal law. The shortcomings that we have identified in this chapter point to a need to further refine both the scope of the provision as well as its intention. We recommend the drafting of elements of crimes as a way to resolve some of the difficulties we point to. The reality of resource predation, especially in Africa, is a subject of major concern that has justifiably attracted considerable attention. The criminal law should certainly play a role in responding to this morose reality; indeed, much of our work stems from the view that accountability in this realm is long overdue, and that in some instances, it is difficult to imagine long term stability in regions without a robust concept of title in natural resources and powerful regulatory regimes to enforce violations of this title. Nevertheless, the foregoing suggests that the criminal law should serve a very principled role in addressing the problem that conforms with a very orthodox understanding of fair punishment. 